\title{
FACTORS AFFECTING THE NUTRITIONAL STATUS OF 3-6-YEAR-OLD CHILDREN ATTENDING ANGANWADIS IN AN URBAN AREA IN KERALA
}

Prabhakumari Chellamma1, Jayasree Chandrasekharan Nair², Sheeja Suresh Lakshmi ${ }^{3}$, Saibunisa Jaleel ${ }^{4}$, Shalini Soman Chellappan 5 , Sofia Shameena ${ }^{6}$, Shan Mohammed Rafi ${ }^{7}$, Sameer Salim ${ }^{8}$, Riya Yohannan ${ }^{9}$

${ }_{1}^{1}$ Professor and HOD, Department of Community Medicine, Travancore Medical College, Kollam, Kerala.

${ }^{2}$ Professor, Department of Community Medicine, Travancore Medical College, Kollam, Kerala.

${ }^{3}$ House Surgeon, Department of Community Medicine, Travancore Medical College, Kollam, Kerala.

${ }^{4}$ House Surgeon, Department of Community Medicine, Travancore Medical College, Kollam, Kerala.

${ }^{5}$ House Surgeon, Department of Community Medicine, Travancore Medical College, Kollam, Kerala.

${ }^{6}$ House Surgeon, Department of Community Medicine, Travancore Medical College, Kollam, Kerala.

${ }^{7}$ House Surgeon, Department of Community Medicine, Travancore Medical College, Kollam, Kerala.

${ }^{8}$ House Surgeon, Department of Community Medicine, Travancore Medical College, Kollam, Kerala.

${ }^{9}$ House Surgeon, Department of Community Medicine, Travancore Medical College, Kollam, Kerala.

\section{ABSTRACT}

\section{BACKGROUND}

Although, Kerala is far ahead of other states of India with regard to most of the health indicators under nutrition is still present here. This is especially true in some urban areas, where the health delivery system at the primary level is inadequate. In spite of the presence of anganwadis, malnutrition is still reported. The study was done to find out the prevalence as well as risk factors for under nutrition in 3-6 year old attending anganwadis. The study was done in an urban area.

The aim of the study is to-

1. Assess the nutritional status of children (3 to 6 yrs.) attending the anganwadis in an urban area in Kerala.

2. Determine the factors associated with poor nutritional status.

\section{MATERIALS AND METHODS}

A cross-sectional study was done in an urban area of Kerala. From Kollam Urban 1 ICDS Project area, 4 wards were randomly selected. Three anganwadis were randomly selected from each ward totalling to 12 anganwadis. All the children 3-6-year-old, attending these 12 anganwadis were included in the study.

\section{RESULTS}

The prevalence of underweight, stunting and wasting were found to be $15.0 \%, 26.7 \%$ and $10.8 \%$, respectively. The factors found to have a significant association with under nutrition were between underweight and low monthly income $(p<0.05)$ between stunting and prematurity $(\mathrm{p}<0.01)$ and stunting and deworming not done in the preceding 6 months $(\mathrm{p}<0.01)$. Wasting was not found to be significantly associated with any of the risk factors studied.

\section{CONCLUSION}

Further exploration and analysis of factors associated with malnutrition is required to implement steps to control under nutrition in children.

\section{KEYWORDS}

Under Nutrition, Anganwadi Children, Prevalence, Determining Factors.

HOW TO CITE THIS ARTICLE: Chellamma P, Nair JC, Lakshmi SS, et al. Factors affecting the nutritional status of 3-6-year-old children attending anganwadis in an urban area in Kerala. J. Evolution Med. Dent. Sci. 2017;6(56):4188-4192, DOI: $10.14260 /$ Jemds/2017/907

\section{BACKGROUND}

Children are the most vulnerable group in any community. They are so because of the processes of growth and development undergone by them during this period. Their survival from birth to five years also constitutes an extremely delicate and crucial period.(1) More than $50 \%$ of all deaths in the developing world occur in children under 5 years of age.

Financial or Other, Competing Interest: None.

Submission 26-04-2017, Peer Review 01-07-2017,

Acceptance 08-07-2017, Published 13-07-2017.

Corresponding Author:

Jayasree Chandrasekharan Nair,

Professor,

Department of Community Medicine,

Travancore Medical College, Kollam, Kerala.

E-mail: jayasree_cs@yahoo.com

DOI: $10.14260 /$ jemds $/ 2017 / 907$
The growth and development of children are intimately related to adequate food, a caring and nurturing social environment and absence of illness.

Under nutrition contributes to nearly half of all deaths in children lower than 5 years and is widespread in Asia and Africa. Worldwide, $23.2 \%$ of children under age 5 had stunted growth in 2015. In 2015, globally 50 million children under 5 were wasted and 17 million were severely wasted. The prevalence of wasting in South Asia is so severe (15\%) that it is approaching the level of a critical public health problem.(2)

Overweight- Worldwide in 2015, 42 million children under age of 5 were overweight up from 31 million in 2000. Trends suggest that this number will continue to rise.

World Bank data indicates that India has one of the world's highest demographics of children suffering from malnutrition said to be double that of Sub-Saharan Africa with dire consequence. In global hunger index, India ranking 67 of the 80 nations with the worst hunger situation places us 
even below North Korea or Sudan. $44 \%$ of children under the age of 5 are underweight, while $72 \%$ of infants have anaemia.

According to India- State hunger index published by the international food policy research institute, the severity of hunger and malnutrition in Kerala is the $2^{\text {nd }}$ lowest in India. According to India- State hunger index, $19 \%$ of the children in Kerala are underweight.

Infections and malnutrition during the childhood takes a heavy toll on the growth potential and ultimate achievement of a healthy life. Children born anywhere in the world have the potential to grow and develop to the same range of weight and height for age, provided they are given the optimum start in life.(3)

Hence, it follows that optimal nutrition, optimal environment and optimal healthcare are definitely crucial. In the case of under five children, all these are related to the mother's health too. Only a healthy mother can give birth to a healthy baby. In India, this was realised very early and our maternal and child health programs are conceived taking this into account. This is true with child survival and safe motherhood programme, Reproductive and Child Health Programme, National Health Mission, etc. All these programs consider the mother and child as a single unit.(4)

The Integrated Child Development Services Scheme, which was started in India in 1975 October takes a step further ahead. Here, the beneficiaries include children 0 to 6 years, pregnant women, lactating mothers and adolescent girls and women of reproductive age group (15-45 yrs.). The package of services provided are supplementary nutrition, immunisation, health checkup, referral services, nutrition and health education and non-formal preschool education.(5) The health checkup includes recording of weight and height of children at periodic intervals, watch over milestones, general checkup to detect disease, malnutrition, etc. every 3 months, treatment for disease like diarrhoea, dysentery, respiratory tract infection, etc., which are widely prevalent, deworming, vitamin A prophylaxis, etc.(6)

So, this study is planned to see how the children aged 3-6 years attending the anganwadis are faring with respect to their nutritional status. The assessment will be based on anthropometric measurements namely weight for age, height for age and weight for height. Other clinical signs were not included because of decreased objectivity and interobserver variations becoming very high.

\section{Objectives}

1. To assess the nutritional status of children ( 3 to 6 yrs.) attending the anganwadis in an urban area in Kerala.

2. To determine the factors associated with poor nutritional status.

\section{MATERIALS AND METHODS}

Study Design

Cross-sectional study.

\section{Study Sample}

3-6-year-old children attending anganwadis in Kollam.

\section{Study Period}

2 months (December 2016 and January 2017).

\section{Study Setting}

Kollam district has 3 urban ICDS projects namely Kollam urban 1 with 189 anganwadis, Kollam urban 2 with 179 anganwadis and Punalur with 74 anganwadis. Of these, the field practice area of Community Medicine Department of Travancore Medical College, Kollam, comes in Kollam urban 1 ICDS project.

The study was conducted in Kollam Urban 1 ICDS project area.

\section{Sample Size}

The prevalence of underweight for age 3-6 years has been found to be $46.46 \%$ according to previous studies.(7) So, by applying $4 \mathrm{pq} / \mathrm{d}^{2}$ the sample size is $4 \times 46.46 \times 53.54 / 9.3 \times 9.3$ $=115$.

\section{Sampling Technique}

4 wards were randomly selected from Kollam Urban 1 ICDS project area. Three anganwadis were selected randomly from each of these wards. So, a total of 12 anganwadis were included in the study.

Pilot study showed that average number of 3-6-year-old children attending each anganwadi comes to $10-15$. So, it is calculated that the required sample size of 115 will be attained if all the 3-6-year-old children attending these anganwadis are covered.

\section{Inclusion Criteria}

3-6-year-old children attending the selected anganwadis.

\section{Exclusion Criteria}

Children with congenital anomalies, metabolic disorders, etc., which interferes with normal feeding.(8)

\section{Data Collection}

The data was collected by using a pretested structured questionnaire by interviewing the mothers of the children.

Measurements of weight, height and mid arm circumference were made by the investigators using standardised beam balance, anthropometric rod and nonstretchable measuring tape, respectively. The measurement procedures were done by the investigators following the methods by previous workers. ${ }^{(9)}$

\section{Data Entry}

Was done in Microsoft excel. Data analysis was done using SPSS version 20. Percentages, frequencies, means, medians, etc. were calculated. Significance testing was done by using Chi-square test. Where necessary, Fischer's exact Test was also used.

Due clearance from the Institutional Ethical Committee was obtained and taking informed consent from the mothers of children, the study was conducted.

\section{RESULTS}

\section{Sociodemographic Factors}

The total number of children studied was 120 . The average number of children in the selected anganwadis was 8-12. Data was available from all the 120 subjects. The sociodemographic details of the children are as follows- 


\begin{tabular}{|c|c|c|}
\hline Age & Frequency $(n=120)$ & Percentage \\
\hline 3-4 years & 36 & 30.0 \\
\hline 4-5 years & 52 & 43.3 \\
\hline 5-6 years & 32 & 26.6 \\
\hline Total & 120 & 100.0 \\
\hline Sex & Frequency $(n=120)$ & Percentage \\
\hline Male & 63 & 52.5 \\
\hline Female & 57 & 47.7 \\
\hline Total & 120 & 100.0 \\
\hline Religion & Frequency $(n=120)$ & Percentage \\
\hline Hindu & 65 & 54.2 \\
\hline Muslim & 41 & 34.2 \\
\hline Christian & 13 & 10.8 \\
\hline Total & 120 & 100.0 \\
\hline $\begin{array}{l}\text { Monthly Income of } \\
\text { the Family }\end{array}$ & Frequency & Percentage \\
\hline$<5000$ & 70 & 58.3 \\
\hline$>5000$ & 50 & 41.7 \\
\hline Total & 120 & 100.0 \\
\hline Family Size & Frequency & Percentage \\
\hline$<2$ & 101 & 84.2 \\
\hline$>2$ & 19 & 15.8 \\
\hline Total & 120 & 100.0 \\
\hline $\begin{array}{c}\text { Education Status of } \\
\text { the Mother }\end{array}$ & Frequency & Percentage \\
\hline Primary & 16 & 13.4 \\
\hline High school & 38 & 31.6 \\
\hline Higher secondary & 60 & 50 \\
\hline Degree or above & 6 & 5 \\
\hline Total & 120 & 100.0 \\
\hline $\begin{array}{c}\text { Employment Status } \\
\text { of the Mother }\end{array}$ & Frequency & Percentage \\
\hline Employed & 28 & 25.3 \\
\hline Not employed & 92 & 76.7 \\
\hline Total & 120 & 100.0 \\
\hline
\end{tabular}

The study group consisted predominantly of male. Majority belong to 4-5-year-old age group. Majority were Hindus followed by Muslims. 58.3\% of the children belonged to families with income less than Rs. 5000 per month. 84 percentages belong to family size less than 2 .

50 percentage mothers belonging to the educational status of higher secondary, 77 percentages of the mothers were unemployed and $23.3 \%$ of the mothers were employed.

\section{Factors Related to Nutritional Status}

\begin{tabular}{|c|c|c|}
\hline Delivery & Frequency & Percentage \\
\hline Normal & 110 & 91.7 \\
\hline Premature & 10 & 8.3 \\
\hline Total & $\mathbf{1 2 0}$ & $\mathbf{1 0 0 . 0}$ \\
\hline Birth Weight & Frequency & Percentage \\
\hline$<2.5 \mathrm{~kg}$ & 9 & 7.5 \\
\hline$>2.5 \mathrm{~kg}$ & 111 & 92.5 \\
\hline Total & $\mathbf{1 2 0}$ & $\mathbf{1 0 0 . 0}$ \\
\hline Initiation of Breastfeeding & Frequency & Percentage \\
\hline After 2 hours of delivery & 30 & 25 \\
\hline Within 2 hours of delivery & 90 & 75 \\
\hline Total & $\mathbf{1 2 0}$ & $\mathbf{1 0 0 . 0}$ \\
\hline $\begin{array}{c}\text { Exclusive Breastfeeding } \\
\text { for 6 Months }\end{array}$ & Frequency & Percentage \\
\hline $\begin{array}{c}\text { Exclusively breastfed for 6 } \\
\text { months }\end{array}$ & 92 & 76.8 \\
\hline $\begin{array}{c}\text { Not exclusively breastfed for } \\
\text { 6 months }\end{array}$ & 28 & 23.2 \\
\hline
\end{tabular}

\begin{tabular}{|c|c|c|}
\hline Total & 120 & 100.0 \\
\hline Weaning & Frequency & Percentage \\
\hline Done at 4-6 months & 44 & 36.7 \\
\hline Not done at 4-6 months & 76 & 63.3 \\
\hline Total & 120 & 100.0 \\
\hline Immunisation & Frequency & Percentage \\
\hline Fully immunised & 114 & 95 \\
\hline Partially immunised & 6 & 5 \\
\hline Total & 120 & 100.0 \\
\hline Vitamin A Prophylaxis & Frequency & Percentage \\
\hline Received the full course & 114 & 95 \\
\hline Not received the full course & 6 & 5 \\
\hline Total & 120 & 100.0 \\
\hline $\begin{array}{l}\text { Supplementary Nutrition } \\
\text { from Anganwadi at least } \\
\text { for } 20 \text { Days a Month }\end{array}$ & Frequency & Percentage \\
\hline Received & 30 & 25 \\
\hline Not received & 90 & 75 \\
\hline Total & 120 & 100.0 \\
\hline $\begin{array}{l}\text { Deworming in the } \\
\text { Preceding } 6 \text { Months }\end{array}$ & Frequency & Percentage \\
\hline Done & 90 & 75 \\
\hline Not done & 30 & 25 \\
\hline Total & 120 & 100.0 \\
\hline $\begin{array}{l}\text { Diarrhoea in the } \\
\text { Preceding } 6 \text { Months }\end{array}$ & Frequency & Percentage \\
\hline$<3$ episodes & 84 & 70 \\
\hline$>3$ episodes & 36 & 30 \\
\hline Total & 120 & 100.0 \\
\hline $\begin{array}{c}\text { Acute Respiratory } \\
\text { Infection in the Preceding } \\
6 \text { Months }\end{array}$ & Frequency & Percentage \\
\hline$<3$ episodes & 76 & 63.3 \\
\hline$>3$ episodes & 44 & 36.7 \\
\hline Total & 120 & 100.0 \\
\hline \multicolumn{3}{|c|}{$\begin{array}{l}\text { Table 2. Factors Related to Nutritional } \\
\text { Status of the Children }\end{array}$} \\
\hline
\end{tabular}

Caesarean was the mode of delivery in $45 \%$ cases. Birth weights of $92.5 \%$ children were more than $2.5 \mathrm{~kg}$. $75 \%$ children had breastfeeding within 2 hours of delivery. $77 \%$ children had exclusive breastfeeding. $36 \%$ only had weaning at 4-6 months. 95\% children were fully immunised. 95\% children received vitamin A prophylaxis. 25\% children received supplementary feedings from anganwadis at least for 20 days in a month. $75 \%$ had deworming in the preceding 6 months. $30 \%$ children had diarrhoea in the preceding 6 months. In the preceding 6 months, 37\% children had more than 3 episodes of ARI.

\section{Anthropometric Measurements}

The anthropometric measurements were computed. Weight, height and mid upper arm circumference were recorded.

The median of height of the group studied came to $94 \mathrm{~cm}$. The median weight was $12.5 \mathrm{~kg}$. The median for body mass index was 19.6 and mid upper arm circumference was $13 \mathrm{~cm}$.

As per WHO (2006) Child Growth Standards,(10) weight for age, height for age and weight for height ( $\mathrm{z}$ score $<2$ standard deviations from the median) are the parameters to be considered while studying malnutrition. In our study, out of 120 children, 18 (15\%) were found to be underweight, 32 (26.6\%) were found to have stunting and 13 (10.8\%) were found to have wasting. 
A body mass index for age of $<2$ standard deviations from the median was found in $26(20.8 \%)$.

\section{Factors Associated with Nutritional Status}

All the 15 risk factors studied, namely monthly income of the family, family size, education status of the mother, employment status of the mother, prematurity, birth weight, time of initiation of breastfeeding, exclusive breastfeeding for 6 months, weaning at 4-6 months, immunisation status, vitamin A prophylaxis, availing of supplementary nutrition from anganwadi for at least 20 days a month, not done deworming for the previous 6 months, more than 3 episodes of acute respiratory infections in the preceding 3 months and more than 3 episodes of acute diarrhoeal disease in the preceding 3 months were cross tabbed against each of the dependant variables, namely underweight, stunted and wasted.

Chi-square test was done for testing the significance. A ' $p$ ' value of $<0.05$ was considered as significant.

Wasting was not found to be significantly associated with any of the risk factors studied.

\begin{tabular}{|c|c|c|c|c|}
\hline \multirow{2}{*}{$\begin{array}{l}\text { Monthly } \\
\text { Income }\end{array}$} & \multicolumn{2}{|c|}{ Weight for Age (n=120) } & \multirow{2}{*}{$\begin{array}{l}\text { Chi- } \\
\text { Square } \\
\text { Value }\end{array}$} & \multirow[b]{2}{*}{ P Value } \\
\hline & $\begin{array}{c}\text { >2 SD of } \\
\text { Median wt. }\end{array}$ & $\begin{array}{c}<2 \text { SD of } \\
\text { Median wt. }\end{array}$ & & \\
\hline $\begin{array}{c}5000 \text { or } \\
\text { more }\end{array}$ & 38 & 12 & \multirow{2}{*}{5.445} & \multirow{2}{*}{0.020} \\
\hline $\begin{array}{l}\text { Less than } \\
5000\end{array}$ & 64 & 6 & & \\
\hline
\end{tabular}

A significant association could be established between underweight only with low monthly income $(p<0.05)$.

\begin{tabular}{|c|c|c|c|c|}
\hline \multirow{2}{*}{$\begin{array}{c}\text { Duration } \\
\text { of } \\
\text { Pregnancy }\end{array}$} & \multicolumn{2}{|c|}{ Height for Age $(n=120)$} & \multirow{2}{*}{$\begin{array}{c}\text { Chi-Square } \\
\text { Value }\end{array}$} & \multirow[b]{2}{*}{ P Value } \\
\hline & $\begin{array}{c}>2 \text { SD of } \\
\text { Median ht. }\end{array}$ & $\begin{array}{c}<2 \text { SD of } \\
\text { Median ht. }\end{array}$ & & \\
\hline Full term & 4 & 6 & \multirow{2}{*}{6.198} & \multirow{2}{*}{0.013} \\
\hline Premature & 84 & 26 & & \\
\hline
\end{tabular}

Stunting was found to be significantly associated with prematurity $(\mathrm{p}<0.01)$.

\begin{tabular}{|c|c|c|c|c|}
\hline \multirow[b]{2}{*}{ Deworming } & \multicolumn{2}{|c|}{ Height for Age $(n=120)$} & \multirow{2}{*}{$\begin{array}{l}\text { Chi- } \\
\text { Square } \\
\text { Value }\end{array}$} & \multirow[b]{2}{*}{ P Value } \\
\hline & $\begin{array}{c}>2 \text { SD of } \\
\text { Median wt. }\end{array}$ & $\begin{array}{c}<2 \text { SD of } \\
\text { Median wt. }\end{array}$ & & \\
\hline $\begin{array}{c}\text { Done in the past } \\
6 \text { months }\end{array}$ & 71 & 19 & \multirow{2}{*}{5.682} & \multirow{2}{*}{0.017} \\
\hline $\begin{array}{l}\text { Not done in the } \\
\text { past } 6 \text { months }\end{array}$ & 17 & 13 & & \\
\hline
\end{tabular}

Deworming not done in the preceding 6 months were significantly associated with stunting $(\mathrm{p}<0.01)$.

\section{DISCUSSION}

In our study, the majority of children belonged to the age group of 4-5 years. This is the predominant age group in most of the referenced studies.

In our study, the percentage of utilisation of supplementary nutrition from the anganwadi for 20 days or more was found to be only $25 \%$. In studies done by Sivanesan et al in coastal Karnataka, it was found to be $95.6 \%$. This difference may be attributed to the relatively higher per capita income of the beneficiaries in this area, which made them think that they could afford to feed the child for home on the remaining days.(11)

In our study, we found that $23.3 \%$ did not practice exclusive breastfeeding for the initial 6 months. 25\% initiated breastfeeding only later than 2 hours after birth. Weaning was started by $4-6$ months only by $36.7 \%$. This is in spite of the high rate of literacy among the mothers. The NFHS4 data shows that in urban Kerala, $45 \%$ do not practice exclusive breastfeeding for the first 6 months. Early initiation was done by only $36.3 \%$. $^{(12)}$ So, the situation is better in the study area, which can be still improved by concerted efforts at health education.

The immunisation and vitamin A prophylaxis coverage in the study area is $95 \%$. These are only $74.3 \%$ and $90 \%$ respectively in urban Kerala according to NFHS4.

Deworming is put forward as one of the strategies for control of malnutrition. Antihelminthic treatment is being delivered from the anganwadis. Still only $75 \%$ had received deworming in the past 6 months. Consumption of deworming tablets periodically has been found to have a significant protective effect against soil transmitted helminthic infections (OR $=0.28, p<0.01)$ in studies by Kattula et al.(13) In spite of the National Mass Deworming campaign, the coverage is not satisfactory. Better awareness creation may help in improving the coverage rate.

$15 \%$ of the children were found to be underweight in our study. According to NFHS4, this is $15.5 \%$ in Kerala. This is comparable to the State data.(14) At the same time, a study conducted by Priyanka et al, the prevalence was 28.3 for underweight.(15)

Prevalence of stunting (26.7\%) is more in the study area when compared to the Kerala value, which is only $19.8 \%$. In the study by Priyanka et al, it was still lower, which is $14 \%$.

Prevalence of wasting is only $10.8 \%$ in the study area, whereas it is a $16.5 \%$ in urban Kerala.(14)

Studies conducted by Binu Areekal et al found out that the percentage of underweight, stunting and wasting were $31.5 \%, 21.8 \%$ and $14.6 \%$, respectively. ${ }^{(16)}$

Whether any long-acting factors are causing the chronic malnutrition in some children in this area has to be explored in further studies.

Even though, several factors related to under nutrition were studied, we found out only six factors to be having a significant association with under nutrition. Monthly family income of Rs. 5000/- or below, mothers being employed, prematurity, not exclusively breastfed during the initial 6 months of life and deworming not done during the preceding 6 months were those factors.

Underweight was found to be significantly associated with the family's low monthly income (Rs. 5000 or below). This agrees with the findings of various studies done on the nutritional status of children. Studies by Yalew et al and also by Ray SK et al show a significant and independent association between underweight and low family income. $(17,18)$

In our study, stunting was found to be associated significantly with prematurity and deworming not having done in the previous 6 months. These factors were found to be associated with stunting in several other studies also. 
Prematurity was identified as a significant risk factor for childhood stunting in studies by Christian P et al, Lee A C et al.(19,20) Helminthic infestations playing a significant role in under nutrition has been brought out in several studies as is evident from the metaanalysis done by Strunz et al.(21)

As far as wasting is concerned, mothers' status of being employed, exclusive breastfeeding not done in the initial 6 months of life and deworming not done in the preceding 6 months were found to be significant. Even though, a higher family income is usually considered positively correlated to good nutrition, it has been seen in several studies that the mother's status of being employed is significantly associated with both acute and chronic malnutrition.(22,23) The mother, due to her absence for long hours from the family, maybe depending on care givers for taking care of the child. Inadequate awareness and lack of commitment on the caregivers' part maybe the reason for the higher level of under nutrition in such children. The role of not exclusively breastfeeding the child for the initial 6 months of life in wasting during later years was found out by Abhishek Kumar et al in their studies in EAG states. (24)

Our study was done in an urban area of Kerala, which is a state that has already achieved many of the sustainable development goals put forwarded to be attained by 2030.(25) The study area has a high female literacy rate of $92.31 \% .{ }^{(26)}$ Anganwadi services are also rendered in a regular basis in the area, but a gap in existing between the awareness and the motivation in utilising the available services. This could be the reason for the still high prevalence rate of under nutrition in this area.

\section{CONCLUSION}

About one fourth of the group is not exclusively breastfed for the first 6 months, $75 \%$ of the children doesn't avail of the supplementary feeding in anganwadis for more than 20 days a month. Low monthly family income, premature birth and deworming not done periodically are found to be predictors for poor nutritional status of the child.

\section{REFERENCES}

[1] Park K. Park's textbook of preventive and social medicine. 23 $3^{\text {rd }}$ edn. Banarsidas Bhanot. Jabalpur 2015.

[2] WHO. Implementation of the global strategy for health for all by the year 2000, second evaluation, eigth report on the world health situation, Vol:4, South-East Asia Region 1993.

[3] ICMR. Growth and development of Indian infants, ICMR Bull 1983.

[4] Govt. of India. Annual report 2013-14, ministry of health and family welfare New Delhi 2014.

[5] Growth monitoring manual: National Institute of Public Cooperation and Child Development 2009.

[6] Integrated child development services. Central technical committee on health and nutrition, AIMS New Delhi 1983.

[7] WHO. Nutrition in preventive medicine. WHO Monograph Sr.No.62-P567, 1976.

[8] Bhardwaj P, Sharma S, Raghav P, et al. Assessment of growth monitoring activities under integrated child development services in western Rajasthan. Int J Med Sci Public Health 2016;5(7):1355-9.
[9] Surwade JB, Salgar AH, Mantri SB. A study of malnutrition in children in the urban field practice area of MIMSR medical college, Latur (MS). Indian journal of recent trends in science and technology 2014;3(1):1-4.

[10] WHO. WHO child growth standards, length/weightage, weight-for-length-weight-for-height and body mass index-for-age. Methods and development 2006.

[11] Sivanesan S, Kumar A, Kulkarni MM, et al. Utilization of integrated child development services (ICDS) scheme by child beneficiaries in coastal Karnataka, Indian. J Comm Health 2016;28(2):132-8.

[12] Rchiips.org/NFHS/pdf/NFHS4/KL - Fact sheet pdf.

[13] Kattula D, Sarkar R, Ajjampur SSR, et al. Prevalence and risk factors for soil transmitted helminth infection among school children in south India. The Indian Journal of Medical Research 2014;139(1):76-82.

[14] Wcd.nic.in/issnip/National Fact\%20 sheet_RSOC\%2002-07-2015.pdf.

[15] Retal P. Prevalence and risk factors of malnutrition in under-fives in urban Karnataka. Int J Community Med Public Health 2016;3(12):3479-86.

[16] Areekal B, Lawrence T, Joseph J, et al. Prevalence of malnutrition among under five children in a semiurban area in Kottayam, Kerala. Journal of Evolution of Medical and Dental Sciences 2014;3(24):6762-71.

[17] Yalew BM. Prevalence of Malnutrition and Associated Factors among Children Age 6-59 Months at Lalibela Town Administration, North WolloZone, Anrs, Northern Ethiopia. J Nutr Disorders Ther 2014;4(1).

[18] Ray SK, Haldar A, Biswas B, et al. Epidemiology of undernutrition. Indian J Pediatr 2001;68(11): 1025-30.

[19] Christian P, Lee SE, Angel DM, et al. Risk of childhood under nutrition related to small for gestational age and pre term birth in low and middle income countries. Int J Epidemiol 2013;42(5):1340-55.

[20] Lee AC, Katz J, Blencowe H, et al. National and regional estimates of term and pre term babies born small for gestational age in 138 low income and middle income countries in 2010. Lancet Glob Health 2013;1(1): e26-36.

[21] Strunz EC, Addiss DG, Stocks ME, et al. Water, sanitation, hygiene, and soil-transmitted helminthic infection: a systematic review and meta-analysis. PLoS Med 2014;11(3):e1001620.

[22] Mittal A, Singh J, Ahluwalia SK. Effect of maternal factors on nutritional status of 1-5yr old children in urban slum population. IJCM 2007;32(4):264-7.

[23] Mother child nutrition.org/malnutrition/about malnutrition/impact of malnutrition.html.last 2017.

[24] Kumar A, Singh VK. A Study of exclusive breast feeding and its impact on the nutritional status of children in EAG states. J Stat Appl Pro 2015;4(3): 435-45.

[25] www.in.undp.org/content.india/en/home/post-2015overveiw.html 2017.

[26] www.censusindia.gov.in/2011 census/dchb/3213 PART A -Kollam pdf 2017. 